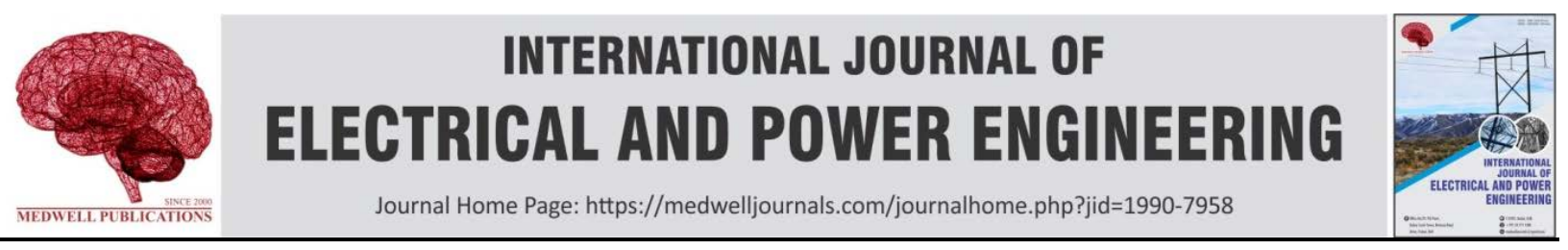

\title{
Flyback Converter Controller by Arduino Uno
}

\author{
Khalid Badr Yass and Ahmed Rashid \\ College of Electrical Engineering, University of Abuja, Abuja, Nigeria
}

Key words: Flayback converter, Arduino Uno, PI controller, MATLAB, open loop, close loop, IC2112

\section{Corresponding Author:}

Khalid Badr Yass

College of Electrical Engineering, University of Abuja, Abuja, Nigeria

Page No.: 88-92

Volume: 13, Issue 06, 2019

ISSN: 1990-7958

International Journal of Electrical and Power Engineering Copy Right: Medwell Publications
Abstract: This study presented a flyback converter that regulates output voltage to give a desired value and can used in many application such as power supply. To give a regulated output voltage from flyback converter a feedback loop with Proportional-Integral (PI) controller is used. A simulation of flyback converter is employed by MATLAB/Simulink. Also a practical implementation is used microcontroller Arduino to control on the duty cycle through IC2112 driver at change in the input voltage or resistive load. The duty controller to create regulate output voltage by using voltage mode control.

\section{INTRODUCTION}

The DC-DC converter transforms a variable or constant DC voltage to regulated output DC voltage. Because of high efficiency and power density in addition to low cost, the switch mode power supplies is extended using than the linear power supplies. The DC-DC flyback converter are widely used, in power electronic application such as photocopy machines, plasma lamp and xenon flash lamps. It converts a fixed DC to variable DC voltage (Mohan et al., 2003; Rashid, 2004). There are many control method used for power converter such as linear control, fuzzy logic, PID, etc. PI control is used because of its simplicity in design and implementation (Sira-Ramirez, 1991; Verma et al., 2013). This study presents with a fly converter controller by Arduino Uno board. It has been selected because of its simplicity in use (Zulkifli et al., 2014; Badamasi, 2014). In this study, PI controller is achieve by programming of Arduino Uno board. The flyback converter is analysed as a feedback system in order to accomplish satisfying stability and time response.

\section{MATERIALS AND METHODS}

Flyback converter schematic: Figure 1 shows a flyback converter which contains of DC battery $\mathrm{V}_{\mathrm{in}}$, switch and output capacitor filter. Diode, transformer (ferrite core) to avoided saturation or two winding magnetic, inductor Lm and output resistance Rout (Erickson and Maksimovic, 2001). The flyback converter is essentially an isolated it operated buck or book. The flyback converter has low cost and simply circuit in addition to multi-output implementation. The transformation of the DC-DC flyback converter is through transformer or inductance by switch on or off. When switch on the the primary of transformer connected to input supply voltage. The primary current increased and energy stored in magnetizing inductance by switch on or off. When switch on the the primary of transformer connected to input supply voltage. The primary current increased and energy stored in wining of transformer. The voltage in the secondary wining has negative polarity, therefore, the diode is reverse biased. The output resistance is supplied from output capacitor. When switch off the primary current decreases and the secondary voltage has positive

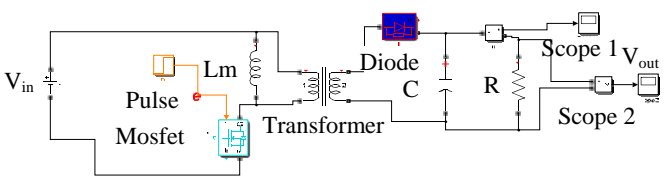

Fig. 1: A flyback converter which contain of DC battery 
polarity, so that, diode is forward biased. The current flows in load and energy transforms from core of transformer to load. Figure 2 shows operated flyback in switch on and off. Operation of converter can be operated in both intervals. A microcontroller needed to generate the pulse width modulation for MOSFET. Arduino used as

x

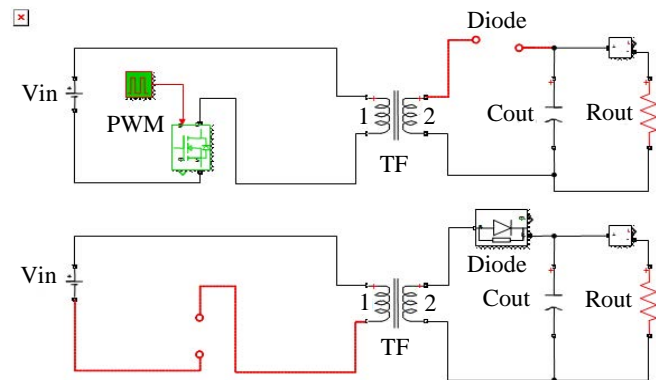

controller $\mathrm{d}$ evice and the output voltage is sensed). through R2 and R3 and sent to pin A2 of Arduino subsequently adjusted the output voltage (Xu et al., 2006). The driven switch is PWM through IC2112. Flyback converter can be control by digital or analog controller. A digital control will be selected here due to of its parameter changes adaptable such as desired output voltage, frequency of switch (MOSFET) and PI controller (proportional-integral parameter).

Feedback control loop by MATLAB: The flyback converter is operating in voltage mode control. The feedback loop of flyback converter is show in Fig 3. The output voltage is compared with reference voltage VREF and sent to PI controller to change duty cycle to adjust output voltage (Sucu, 2011).

Fig. 2: Operated flyback

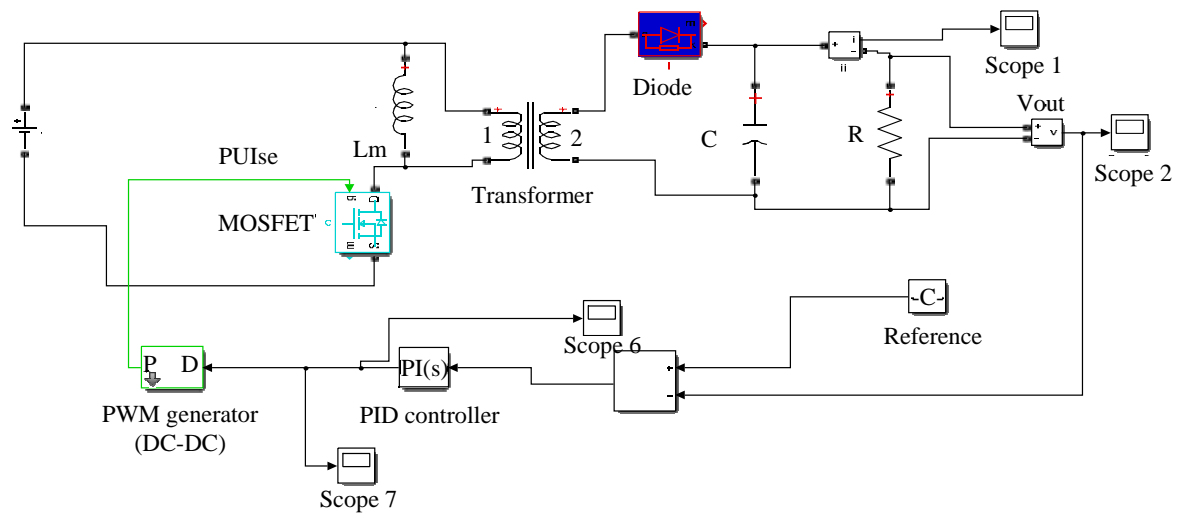

Fig. 3: Feedback loop of flyback converter

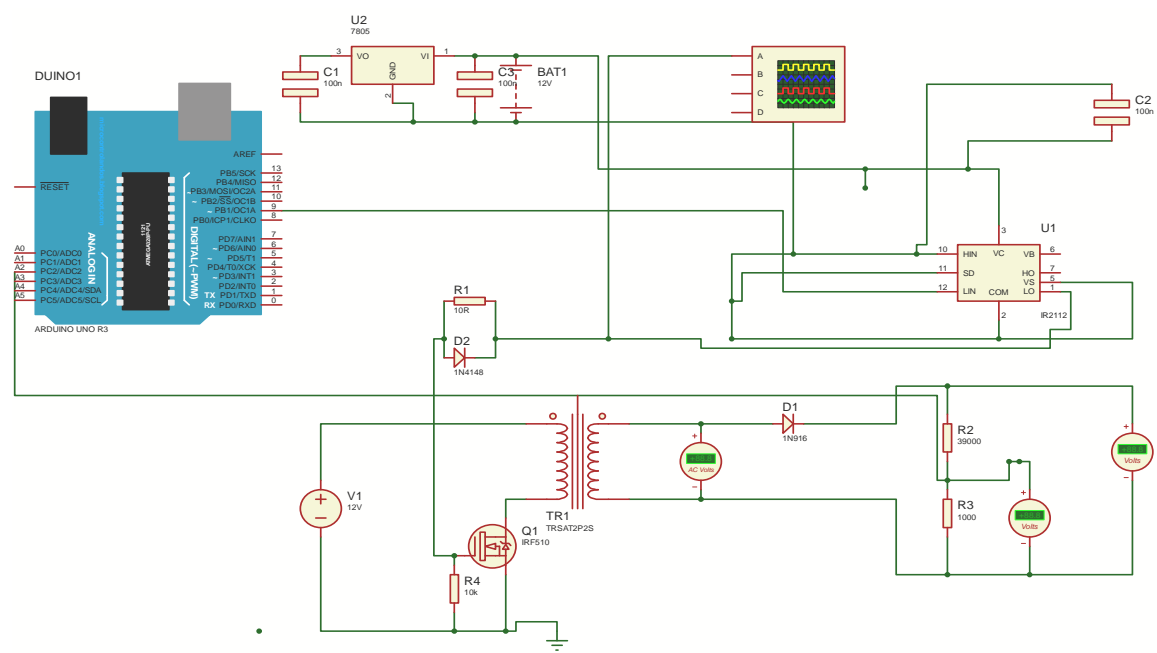

Fig. 4: Flyback converter with feedback loop 
Int. J. Elec. Power Eng., 13 (6): 88-92, 2019
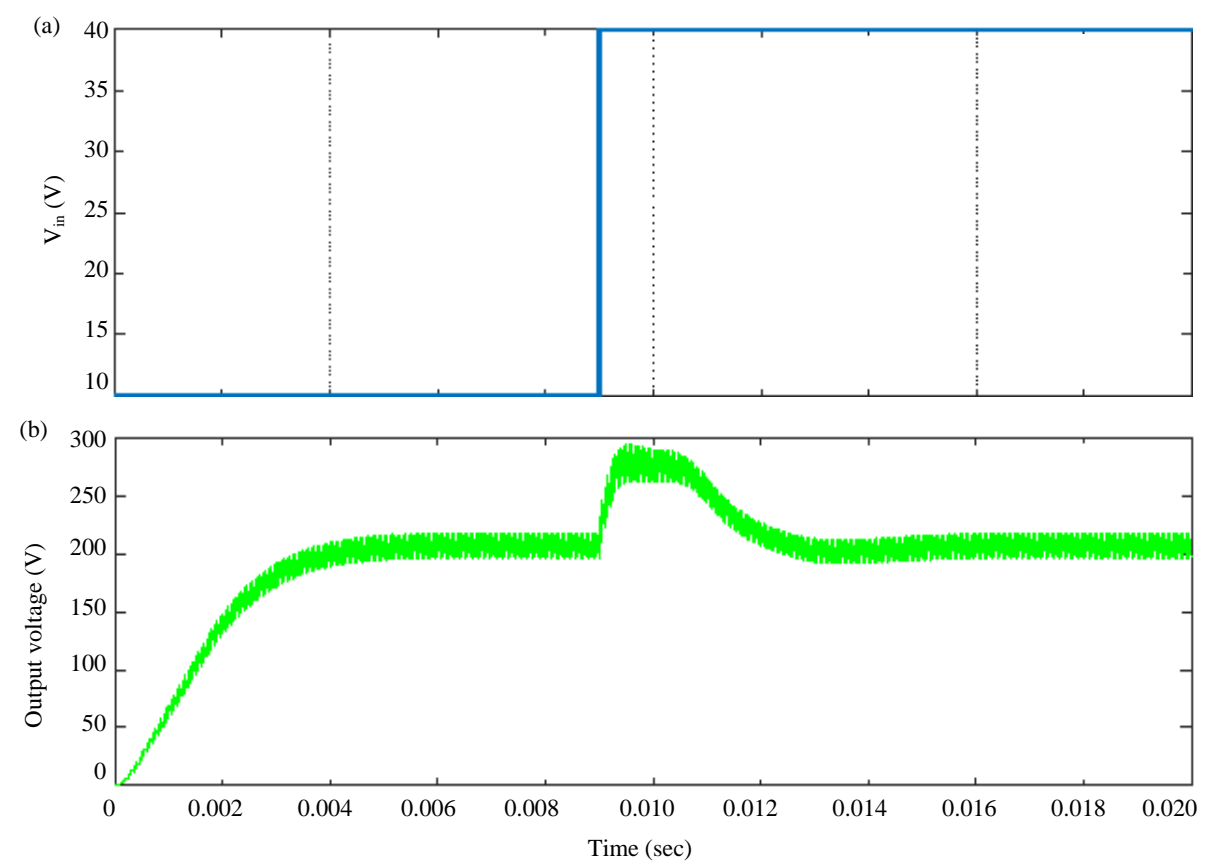

Fig. 5: Pulse width modulation and controlled on the output voltage

\begin{tabular}{ll} 
Table 1: Component & \\
\hline Variables & Values \\
\hline Mosfet & IRF540 \\
Capacitor & $0.61(\mu \mathrm{F})$ \\
$\mathrm{V}_{\text {in }}$ & $12(\mathrm{~V})$ \\
$\mathrm{V}_{\text {out }}$ & $200(\mathrm{~V})$ \\
$\mathrm{R}$ & $800(\Omega)$ \\
Inductor & $0.44(\mathrm{mH})$ \\
Ic & 2112 \\
fs & $20(\mathrm{kHz})$ \\
\hline
\end{tabular}

Table 2:The output voltage constant with change in the input voltage

\begin{tabular}{lcc}
\hline Input voltage & Output voltage & Output current \\
\hline 9 & 200.322 & 0.2504 \\
11 & 200.366 & 0.25045 \\
12 & 200 & 0.250 \\
13 & 200.86 & 0.25107 \\
14 & 200.98 & 0.25112 \\
\hline
\end{tabular}

Table 3: The output voltage constant with change in load resistance

\begin{tabular}{lcc}
\hline Load resistance in $(\Omega)$ & Output voltage in $(\mathrm{V})$ & Output current in (amp) \\
\hline 500 & 200.222 & 0.4004 \\
600 & 200.3256 & 0.3338 \\
800 & 200.3451 & 0.250 \\
900 & 200.877 & 0.2231 \\
1000 & 200.9367 & 0.2009 \\
\hline
\end{tabular}

Feedback loop regulation of flyback converter: The control part will be implemented by Arduino Uno board and all parameter circuit with feedback system show in Fig. 3 and 4. The pulse width generator delivers a rectangular signal at frequency $20000 \mathrm{khz}$ and duty cycle $\mathrm{D}=0.4$ from Arduino Uno through IC2112 driver to supply gate of switch. The output voltage is measured through resistances $\mathrm{R} 2$, R3. The output voltage divider is sent to Arduino Uno to correct any change in the output voltage or input voltage of the converter. The output voltage divider should not exceed analog input voltage of Arduino Uno (5V). Figure 4 and 5 show flyback converter with feedback loop (Table 1-3).

Component: A DC voltage source used to supply the flyback converter. The fly back converter gives output voltage greater than input voltage, according to PWM produced by Arduino board. The pulse signal from Arduino v supples to semiconductor through IC2112 driver.

\section{RESULTS AND DISCUSSION}

The flyback converter is designed and simulated by using MATLAB R2017A. The Arduino provided pulse width modulation and controlled on the output voltage by increase or decrease the duty cycle. Figure 5 show when occurred change in input voltage from (10-40) $\mathrm{V}$ the microcontroller (Arduino Uno) corrected any change to give desired Voltage (200 V).

Hardware implementation: Figure 6 shows the hardware implement of flyback converter with Arduino controller. A PWM signal is generated by 


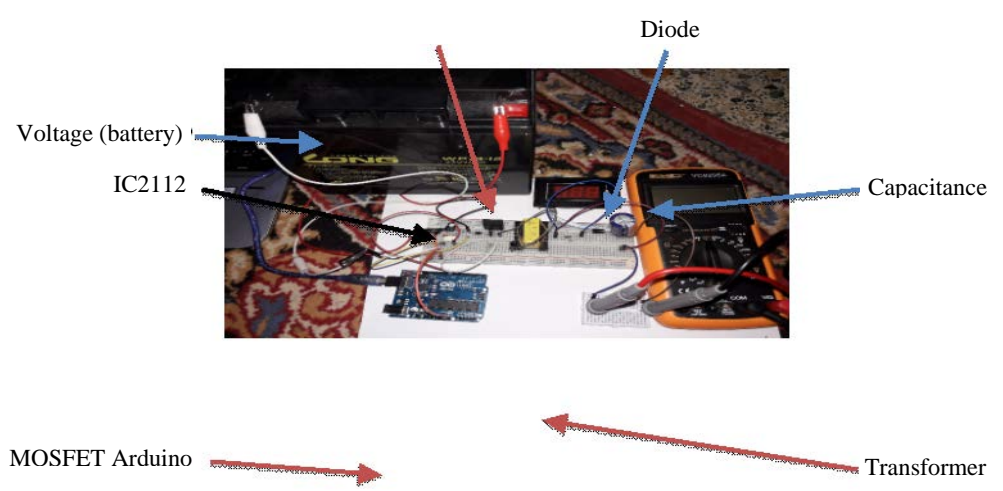

Fig. 6: The hardware circuit

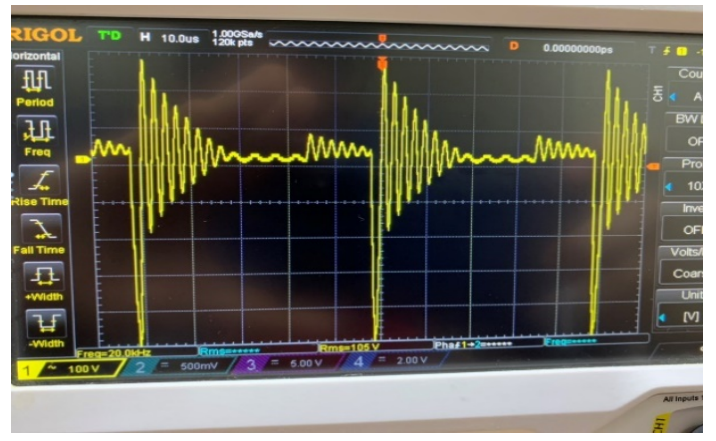

Fig. 7: The output voltage from transformer

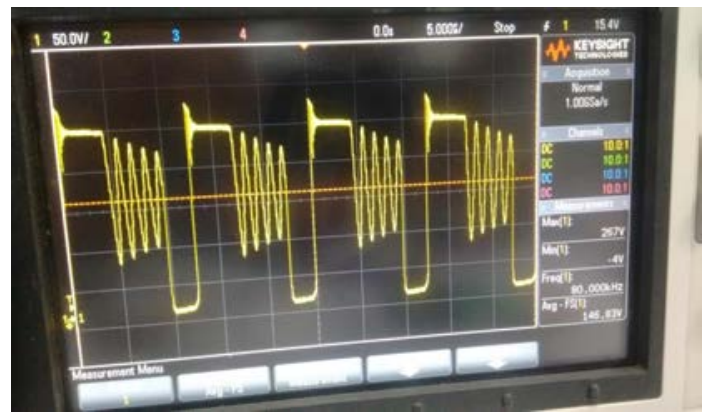

Fig. 8: The waves at primary

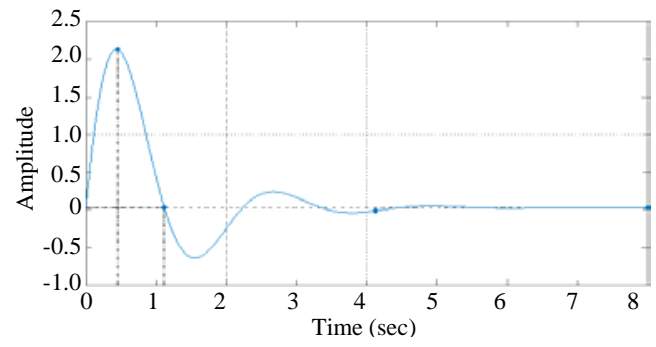

Fig. 9: Step response

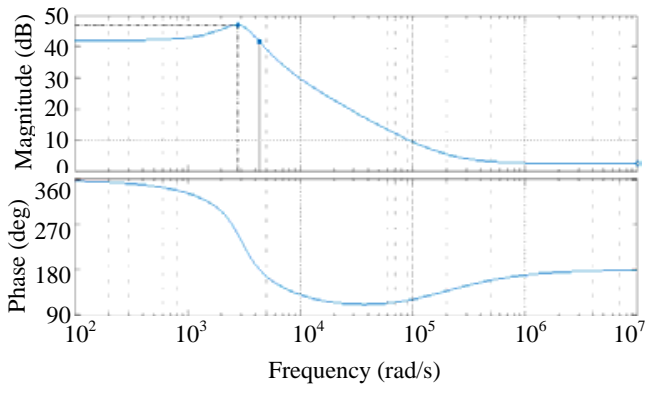

Fig. 10: Bode plots $\left(\mathrm{V}_{\text {out }} / \mathrm{V}_{\text {in }}\right.$ :from:d, To: vo)

Arduino in order to trigger the switch through IC driver (IC2102). The frequency of the PWM is the same that in the simulated circuit.

State space of flyback converter: Obtained transfer function of the flyback converter to determine the Bode plots and step response and ensure the system in stable, show in Fig. 8 and 9. We can find state space from (Sucu, 2011; Ramanarayanan, 2006; Chen et al., 1999). During switch on:

$$
\mathrm{A} 1=\left[\begin{array}{cc}
0 & 0 \\
0 & \frac{1}{\mathrm{RC}}
\end{array}\right], \mathrm{B} 1=\left[\begin{array}{c}
\frac{1}{\mathrm{Lm}} \\
0
\end{array}\right], \mathrm{C} 1=\left(\begin{array}{ll}
0 & 1
\end{array}\right)
$$

During switch off:

$$
\begin{gathered}
\mathrm{A} 2=\left[\begin{array}{cc}
0 & -\frac{\mathrm{n}}{\mathrm{Lm}} \\
\frac{\mathrm{n}}{\text { Cout }} & \frac{1}{\mathrm{RCout}}
\end{array}\right], \mathrm{B} 2=\left[\begin{array}{l}
0 \\
0
\end{array}\right], \mathrm{C} 2=(01) \\
\mathrm{A}=\mathrm{A} 1{ }^{*} \mathrm{~d}+\mathrm{A} 2(1-\mathrm{d}) \\
\mathrm{B}=\mathrm{B} 1{ }^{*} \mathrm{~d}+\mathrm{B} 2(1-\mathrm{d}) \\
\mathrm{C}=\mathrm{C} 1 * \mathrm{~d}+\mathrm{C} 2(1-\mathrm{d}) \\
\mathrm{E}=\mathrm{E} 1{ }^{*} \mathrm{~d}+\mathrm{E} 2(1-\mathrm{d})
\end{gathered}
$$


Int. J. Elec. Power Eng., 13 (6): 88-92, 2019

$$
\begin{gathered}
\frac{\text { Vout }}{\text { Vin }}=c(\text { SI-A })^{\tau}(-1) \\
B=\frac{0.0495 s^{2}+9902 s+2.475 e 05}{s^{2}+2050 s+8.96 e 06}
\end{gathered}
$$

\section{CONCLUSION}

The flyback converter controlled by microcontroller (Arduino Uno board) is achieved. Arduino Uno is used to control on flyback converter by generated PWM. The flyback converter is implemented by PI controller which accomplished by Arduino Uno board. PI controller used to reduce over shoot and steady state errors and gave desired output voltage.

\section{REFERENCES}

Badamasi, Y.A., 2014. The working principle of an Arduino. Proceedings of the 2014 11th International Conference on Electronics, Computer and Computation (ICECCO), September 29-October 1, 2014 , IEEE, A buja, Nigeria, ISBN:978-1-4799-4108-7, pp: 1-4.

Chen, T.H., W.L. Lin and C.M. Liaw, 1999. Dynamic modeling and controller design of flyback converter. IEEE. Trans. Aerosp. Electron. Syst., 35: 1230-1239.

Erickson, R.W. and D. Maksimovic, 2001. Fundamentals of Power Electronics. 2nd Edn., Wolters Kluwer, New York, USA., ISBN:0-7923-7270-0, Pages: 883.
Mohan, N., T. Undeland and W. Robbins, 2003. Power Electronics Converters, Applications and Design. Wiley, Hoboken, New Jersey, USA.

Ramanarayanan, V., 2 006. Course Material on Switched Mode Power Conversion. 2nd Edn., Indian Institute of Science, Bengaluru, India, Pages: 460.

Rashid, M.H., 2004. Power E lectronics Circuits, Devices and Applications. 3rd Edn., Prentice Hall, New York.

Sira-Ramirez, H., 1991. Nonlinear P-I controller design for switchmode DC-to-DC power converters. IEEE. Trans. Circuits Syst., 38: 410-417.

Sucu, M., 2011. Parametric average value modeling of flyback converters in CCM and DCM including parasitics and snubbers. Ph.D Thesis, UBC Okanagan, Kelowna, Canada.

Verma, S., S. Singh and A. Rao, 2013. Overview of control techniques for DC-DC converters. Res. J. Eng. Sci., 2: 18-21.

Xu, M., J. Sun and F.C. Lee, 2006. Voltage divider and its application in the two-stage power architecture. Proceedings of the IEEE 21th Annual International Conference and Exposition on Applied Power Electronics (APEC'06), March 19-23, 2016, IEEE, Dallas, Texas, USA., ISBN:0-7803-9547-6, pp: 1-7.

Zulkifli, S.A., M.N. Hussin and A.S. Saad, 2014. MATLAB-Arduino as a low cost microcontroller for 3 phase inverter. Proceedings of the 2014 IEEE International Student Conference on Research and Development, December 16-17, 2014, IEEE, Batu Ferringhi, Malaysia, ISBN:978-1-4799-6428-4, pp: 1-5. 